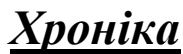

\title{
Національний природний парк «Олешківські піски»: народження нової природоохоронної структури на Херсонщині
}

21 листопада 2011 року підписано штатний розклад новоствореного на Херсонщині національного природного парку «Олешківські піски». Згідно Указу площа НПП становить 8020,36 га, в т.ч. в постійному користуванні знаходиться 5222,30 га. Також відповідно до цього ж указу після заходів щодо вивільнення (протягом 2010 2013 років) від вибухонебезпечних предметів земельних ділянок колишнього авіаційного полігону «Херсон» Міністерства оборони України, ці землі мають бути передані у постійне користування національному природному парку «Олешківські піски».

Під охорону взяті унікальні ландшафти псамофітних різнотравно-дерновиннозлакових степів, піщаних дюн (кучугур) та листяних гайків в міжкучугурних зниженнях. Територія НПП має значний рекреаційний потенціал місцевого та загальнодержавного значення і повністю охоплюється Нижньодніпровським регіональним екокоридором, що являє собою нижньодніпровську ділянку меридіонального Дніпровського екокоридору Національної екомережі України.

Сьогодні НПП «Олешківські піски» складається з восьми окремих фрагментів площею від 17,9 до 5222,3 га. Найбільша ділянка парку знаходиться на Козачелагерській арені і входить до науково-дослідного природоохоронного відділення «Раденське». Саме тут розташовано 5222,3 га території, які передаються парку у постійне користування. На території Чалбаської арени розміщено «Буркутське» науково-дослідне відділення, яке займає територію 1033,5 га, що не вилучається у землекористувачів.

Серед основних завдань НПП є організація моніторингових досліджень над абіотичними та біотичними системами парку, проведення робіт 3 інвентаризації біорізноманіття парку, дослідження стану раритетного фіторізноманіття, підготовка наукових та науково--популярних публікацій, матеріалів для сайту, розробка екскурсійних маршрутів та різної часової тривалості для різних цільових груп рекреантів, розробка англомовних варіантів рекламних проспектів, проведення освітньо-виховної діяльності з середніми та вищими навчальними закладами тощо.

Першочерговим завданням адміністрації парку є розширення меж території до науково обгрунтованих (Бойко, Мойсієнко, 2008, Бойко та ін., 2008, 2009, Наукове обгрунтування..., 2008, Ходосовцев та ін., 2008, 2009а, б, Khodosovtsev at al., 2011). Останнє обумовлено тим, що: 1) функціонування заповідного об'єкту на частині арени викличе проблеми з виконанням покладеної на нього функції охорони природи; 2) представлені в обгрунтуванні арени входять до природного ядра Дніпровського екокоридору Національної екомережі України, 3) зменшення площі НПП призвело до порушення оптимальної структури, 4) до складу парку не увійшли ділянки особливої природоохоронної (созологічної) цінності; 5) в представленому варіанті заповідний об'єкт виявився розділеним на 8 віддалених ділянок і за своїми масштабами не відповідає обгрунтованим мінімальним розмірам, необхідним для тривалого збереження біологічного різноманіття; 6) землевласники, якими є 9 сільських рад, прийняли рішення про входження своїх земель до НПП.

Ходосовиев О.Є., Мойсієнко I.І., Пилипенко I.О., Бойко М.Ф. 